\section{POLYMERIC MIXED MATRIX MEMBRANES INCORPORATED WITH GRAPHENE OXIDE FOR $\mathrm{H}_{2} / \mathrm{CO}_{2}$ SEPARATION}

\author{
Rosiah Rohania*, Hannaneh Milani Kalkhorana, Ying Tao Chunga,b
}

aChemical Engineering Program \& Research Centre for Sustainable Process Technology, Faculty of Engineering and Built Environment, Universiti Kebangsaan Malaysia, 43600 Bangi, Selangor, Malaysia bDepartment of Chemical and Petroleum Engineering, Faculty of Engineering, Technology and Built Environment, UCSI University (Block E) Kuala Lumpur Campus Jalan Mandarina Damai 1, 56000 Cheras, Kuala Lumpur, Malaysia
Article history

Received

14 June 2018

Received in revised form

14 January 2019

Accepted

23 January 2019

Published online

18 April 2019

*Corresponding author rosiah@ukm.edu.my

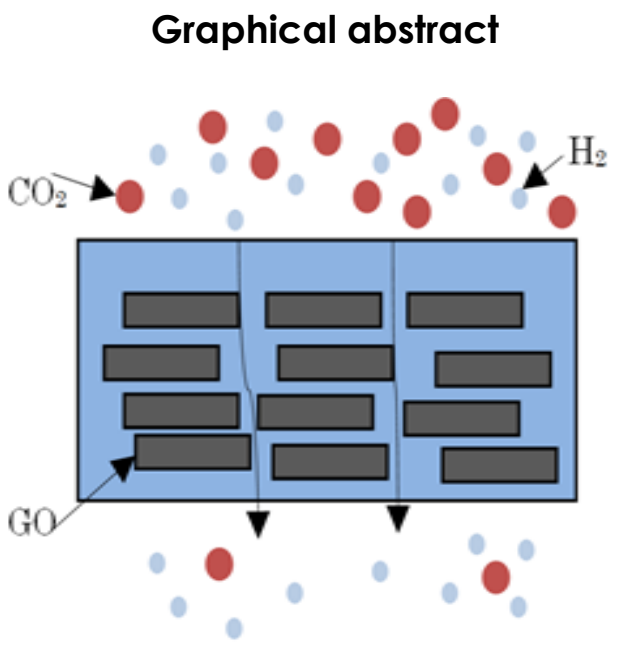

\begin{abstract}
Biohydrogen is a potential alternative for fossil fuels and it can be produced from POME fermentation. Membrane technology has been a prominent separation approach for $\mathrm{H}_{2}$ purification. However, membranes yield weakness in tradeoff between permeability and selectivity. The main objective of this project is to develop mixed matrix membrane with different polymeric bases of Polysulfone (PSF) and Polyimide (PI) with graphene oxide (GO) incorporation as inorganic filler for $\mathrm{H}_{2} / \mathrm{CO}_{2}$ separation. Gas permeability and selectivity results indicated that PI/GO membrane with 1 wt\% of $\mathrm{GO}$ has the highest $\mathrm{H}_{2}$ and $\mathrm{CO}_{2}$ permeability at 501 GPU and 595 GPU at 1 bar, respectively, $\mathrm{H}_{2} / \mathrm{CO}_{2}$ selectivity of 1.01 at 5 bar and highest $\mathrm{H}_{2}$ purity of $83 \%$. FESEM analysis indicated changes in the pore size and top layer of membranes due to the presence of GO. Zeta potential analysis proved that PI/GO $1 \mathrm{wt} \%$ membranes is highly negativecharged $(-56 \mathrm{mV})$. Contact angle results showed a decrease in contact angle value with the addition of GO. It can be concluded that PI/GO 1 wt\% membranes demonstrated better results in the aspects of permselectivity and physicochemical properties compared to PSF membranes.
\end{abstract}

Keywords: POME, biohydrogen, MMMs, graphene oxide, gas separation

\begin{abstract}
Abstrak
Biohidrogen merupakan satu alternatif yang berpotensi untuk bahan api fosil dan ia dapat dihasilkan daripada penapaian POME. Teknologi membran merupakan teknologi pemisahan yang terkenal untuk penulenan $\mathrm{H}_{2}$. Namun, membran mempunyai kelemahan dalam penukaran antara kebolehtelapan dan pemilihan. Objektif utama kajian ini adalah untuk membentuk membran matriks bercampur yang berasaskan polimer polisulfona (PSF) dan polimida (PI) dengan penambahan grafin oksida (GO) sebagai pengisi bukan organik untuk pemisahan $\mathrm{H}_{2} / \mathrm{CO}_{2}$. Keputusan analisis kebolehtelapan dan pemilihan gas membuktikan bahawa membran PI/GO dengan 1 w $\%$ GO mempunyai prestasi tertinggi dengan ketelapan $\mathrm{H}_{2}$ dan $\mathrm{CO}_{2}$ pada 501 GPU dan $595 \mathrm{GPU}$ pada 1 bar, pemilihan $\mathrm{H}_{2} / \mathrm{CO}_{2}$ pada 1.01 pada 5 bar dan ketulenan $\mathrm{H}_{2}$ yang tertinggi iaitu $83 \%$. Analisis FESEM telah menunjukkan perubahan saiz liang dan lapisan atas membran dengan kehadiran GO. Analisis keupayaan zeta menunjukkan membran PI/GO 1wt\% adalah bersifat caj negatif yang tinggi ($56 \mathrm{mV}$ ). Keputusan sudut sentuhan juga menunjukkan penurunan nilai sudut sentuhan dengan penambahan GO. la dapat disimpulkan bahawa membran
\end{abstract}


$\mathrm{PI}$ /GO Iwt\% menunjukkan keputusan yang lebih baik dalam aspek kepilihan dan sifat fisikokimia berbanding denagn membran PSF.

Keywords: POME, biohidrogen, MMMs, grafin oksida, pemisahan gas

(c) 2019 Penerbit UTM Press. All rights reserved

\subsection{INTRODUCTION}

We use energy sources in our daily lives. Extreme use of these energy sources like fossil fuel cause environmental pollutions. For this reason, it is necessary to find an alternative clean fuel such as hydrogen which is known to be environmental friendly. One of the main resources to produce hydrogen is through anaerobic fermentation of Palm Oil Mill Effluent (POME), in which hydrogen is produced along with carbon-dioxide as the final products. It is important to purify hydrogen in order for it to be used as fuel. Separation of hydrogen from impurities like carbon dioxide has been done using different technologies such as pressure and temperature swing adsorption, and cryogenic distillation which is known to be an expensive energy intensive process. Membrane technology is also a well-known technique due to its ease of operation and simplicity.

Polymeric membranes are known to be the most popular kinds of membrane used in gas separation industry because of their excellent basic transport properties, high ability of process, and their low cost [1]. A good polymeric membrane should have both high selectivity and permeability. However, membrane can only achieve either high selectivity or high permeability depending on the types of polymers. Other weaknesses of membrane include the properties of temperature resistance and mechanical strength [2-4]. Several studies have reported on the enhancement of membrane properties by introducing blend membranes or mixed matrix membranes (MMM) with the incorporation of inorganic fillers such as zeolite [5].

In this project, Polysulfone (PSF) has been selected as the basic polymer due to its rigid, strong, and transparent thermoplastic properties. It is one of the most used polymeric membrane materials for gas separation (such as stripping $\mathrm{CO}_{2}$ from natural gas) due to its low cost, mechanical strength, thermal, and chemical stability [6]. However, high plasticization pressure is one of the major concerns for this polymer [7]. On the other hand, polyimide (PI) has been chosen for its excellent physical and chemical properties with good thermal stability and high glass transition temperature [8,9]. Another potential way to enhance membrane properties is through the incorporation of graphene oxide (GO) as inorganic filler. This is possible due to its good potential for easy membrane formation, solution- processable casting, size controllable, possible pore engineering. Besides, it has excellent gas-barrier properties as polymer composites [10].

Hence, the main objective is to improve the performance of PSF and PI membranes in terms of permselectivity and physicochemical properties by adding graphene-oxide (GO) as inorganic filler in different concentrations, which is essential in the separation of $\mathrm{H}_{2} / \mathrm{CO}_{2}$ from the fermented gas mixture of POME.

\subsection{METHODOLOGY}

\subsection{Materials}

Polysulfone in granule form (PSF, Udel polysulfone P1700 ) and polyimide in fibre form (P84 co-polyimide BTDA-TDI/MDI, co-polyimide of $3,3^{\prime}, 4,4^{\prime}$ benzophenone tetracarboxylic dianhydride and $80 \%$ methylphenylenediamine $+20 \%$ methylene diamine) were purchased from Goodfellow Cambridge Limited. The solvent used, 1-methyl-2-pyrrolidinone (NMP) was purchased from Merck KGaA. The properties of polymers and solvent are listed in Table 1. Graphene oxide (GO), prepared using Hummer's method as described in the study by Mahmoudi et al. [39] was supplied by the Membrane Lab, Universiti Kebangsaan Malaysia (UKM) [11].

Table 1 Properties of polymers and solvent

\begin{tabular}{llll}
\hline Properties & PSF & PI & NMP \\
\hline Glass transition temperature $\left({ }^{\circ} \mathrm{C}\right)$ & 185 & 300 & - \\
Density $\left(\mathrm{g} / \mathrm{cm}^{3}\right)$ & 1.24 & 1.2 & 1.033 \\
Molecular weight $(\mathrm{g} / \mathrm{mol})$ & 42.52 & 80,000 & 99.13
\end{tabular}

\subsection{Synthesis of Polymeric Membranes}

The basic polymeric membrane, PSF and PI, were prepared via phase inversion method with the polymer proportion of $18 \mathrm{w}+\%$ in $82 \mathrm{wt \%}$ of solvent. The solution was dissolved in NMP at $60{ }^{\circ} \mathrm{C}$ on a hot plate under continuous stirring (500 RPM) for 12 hours to obtain a homogeneous mixture. Next, the solution was degassed for 30 minutes in a sonicator. After degassing, the solution was casted at room temperature with a thickness of 200 micron. Then the casted membrane was put in a cold-water bath (18 
$\left.{ }^{\circ} \mathrm{C}\right)$ for one hour. Finally, it was rinsed with distilled water $\left(25^{\circ} \mathrm{C}\right)$ before it was kept at room temperature for 24 hours. In order to add GO into the polymeric solution in three different concentrations $(0.1,0.5,1$ wt\%), it was first dissolved completely in NMP for a few hours, prior to addition polymeric solution under continuous stirring at 200 RPM for 12 hours at room temperature. A similar casting procedure was then performed as shown in Figure 1.
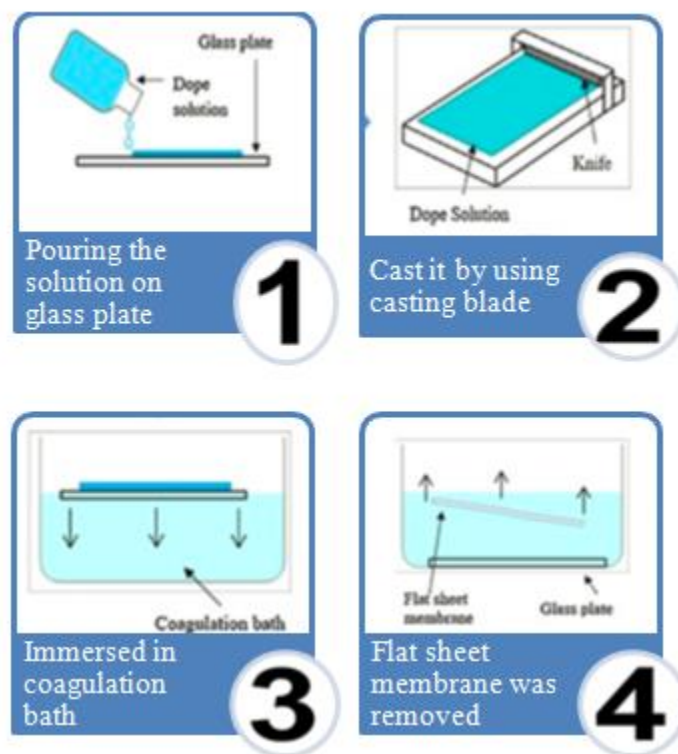

Figure 1 Membrane fabrication procedures

\subsection{Characterizations}

The resultant polymeric membrane and polymericGO membranes were characterised with the following characterisation analyses:

a. FTIR (Fourier Transform Infrared Radiation): To identify the functional groups in the sample [12]. It was determined by using Nicolet 6700 FTIR-ATR (Thermo Scientific, USA), whereby each sample was cut in the measurement of $1 \mathrm{~cm} \times 1 \mathrm{~cm}$ and analysed in the wave number of $400-4000 \mathrm{~cm}-1$.

b. Contact Angle measurement: To determine the hydrophobicity/hydrophilicity of the samples [13]. It was measured using contact angle meter (Kruss GmbH, Germany) with Drop Shape Analysis software with accuracy of $+/-0.10$.

c. Zeta potential analysis: To determine the surface charge of the membrane [14]. The zeta potential of membrane surface was measured in water at $\mathrm{pH} 7$ using polystyrene latex particles as the tracer particles, with Malvern Surface Zeta Potential Cell (Malvern Instruments, UK) by applying field strength of $25 \mathrm{~V} / \mathrm{cm}$.

d. Tensile Strength Test (Mechanical properties): To measure the mechanical strength of a material by providing the burden of the opposing forces in a straight line [15]. Each membrane sample was cut with the measurement of $25 \mathrm{~mm} \times 75 \mathrm{~mm}$ and was put in the grips. It was analyzed using CT3-100 Texture Analyzer (Brookfield, USA), with the tension test trigger, deformation, and speed set at $0.5 \mathrm{~g}, 15 \mathrm{~mm}$ and $5 \mathrm{~mm} / \mathrm{s}$, respectively. Membranes were dried and tested at ambient conditions.

e. FESEM (Field Emission Scanning Electron Microscopy): To obtain the membrane surface and cross-sectional morphology [16]. It was carried out by using FESEM (Zeiss 55VP SUPRA, USA), in which the membranes samples were initially prepared by soaking in liquid nitrogen $\left(\mathrm{N}_{2}\right)$ to crack membranes' top and cross section.

\subsection{Gas Performance Testing}

a) Gas Permeance Study

Gas permeance was measured using an apparatus which consisted of a bubble flow meter and pressure gauge at the bottom of the cell. The gas separation performance was evaluated in terms of selectivity and permeability with pure compositions of $\mathrm{CO}_{2}$ and $\mathrm{H}_{2}$ at pressures from 1 to 5 bar. The gas permeation equipment is shown in Figure 2. Based on the study by Mohamad et al. [40] the gas inlet ratio for $\mathrm{H}_{2} / \mathrm{CO}_{2}$ was confirmed at equal proportion [17]. Hence, the specially-mixed gas consisted of $50 \%$ of $\mathrm{H}_{2}$ and $50 \%$ $\mathrm{CO}_{2}$ (supplied by NIG gases Sdn. Bhd.) was flowed into the gas permeation test unit, as a substitution of fermented gas from POME for further performance evaluation. The permeability and ideal $\mathrm{H}_{2} / \mathrm{CO}_{2}$ selectivity were calculated using Equations 1 to 3 , respectively.

$$
\frac{\mathrm{P}_{\mathrm{Su}}}{\mathrm{L}}=\frac{1}{\mathrm{SP}}
$$

$\frac{P_{\mathrm{H}_{2}}}{\mathrm{~L}}=\frac{\Gamma}{\Delta \mathrm{P}}$

$\alpha=\frac{\mathrm{P}_{\mathrm{H}_{2} i_{\mathrm{L}}}}{\mathrm{P}_{\mathrm{LU}} \mathrm{U}_{Z_{\mathrm{L}}}}$

Where:

$J=$ flux

$\Delta P=$ pressure $(\mathrm{KPa})$

$L=$ membrane thickness $(\mu \mathrm{m})$

$P=$ permeability

$\propto=$ selectivity 


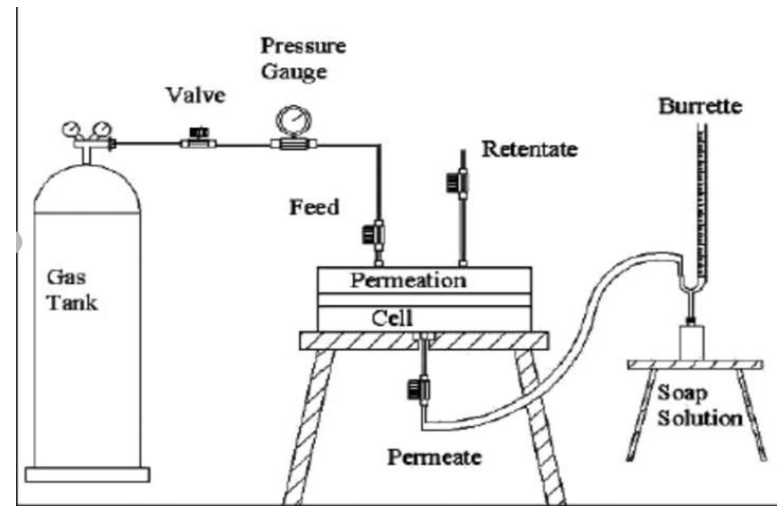

Figure 2 Gas permeation equipment schematic diagram

\section{b) Gas composition study}

Gas chromatography (GC) (SRI 8600C, USA) was used to analyze the gas composition, permeation, and retention after separation. The peak readings (retention time) for composition of $\mathrm{H}_{2}$ and $\mathrm{CO}_{2}$ were taken at 1.6 minutes and 10.5 minutes, respectively.

\subsection{RESULTS AND DISCUSSION}

\subsection{FTIR Analysis}

In Figure 3 (a) it can be seen that the peaks reflected the presence of respective functional groups in PSF. All these functional groups showed the existence of $\mathrm{C}-\mathrm{O}$ bond $\left(2968 \mathrm{~cm}^{-1}\right), \mathrm{O}=\mathrm{S}=\mathrm{O}$ bond $\left(1245 \mathrm{~cm}^{-1}\right)$, which is a functional group in PSF, while peaks of $1294 \mathrm{~cm}^{-1}$ and $1151.4 \mathrm{~cm}^{-1}$ were related to asymmetric and symmetric stretching vibrations which originated from $\mathrm{C}-\mathrm{O}-\mathrm{C}$ bond. The peaks between wave numbers of $2900 \mathrm{~cm}^{-1}$ and $3100 \mathrm{~cm}^{-1}$ were associated to aromatic groups and the stretching vibration of $\mathrm{C}-\mathrm{H}$ bond. For pure $\mathrm{PI}$ membranes (see Figure 3 (b)), the symmetric and asymmetric stretching of the $\mathrm{C}=\mathrm{O}$ group (imide groups) were observed at 1727.6 and $1780 \mathrm{~cm}^{-1}$. The peak related to $\mathrm{C}=\mathrm{C}$ stretching of the aromatic ring was observed at $1512 \mathrm{~cm}^{-1}$. The band observed at $1164 \mathrm{~cm}^{-1}$ was ascribed to the presence of $\mathrm{C}_{6} \mathrm{H}_{4}$. The peak due to aromatic ring bending vibrations was observed at $863 \mathrm{~cm}^{-1}$. These results were in accordance with previous studies [18, 21, 22]. Furthermore, the addition of $\mathrm{GO}$ into $\mathrm{Pl}$, the peaks of $\mathrm{O}-\mathrm{H}$ and $\mathrm{C}-\mathrm{O}-\mathrm{C}$ was observed at peaks of 1367.9 and $1105.5 \mathrm{~cm}^{-1}$, respectively. It has been proven that, due to the existence of oxygenated functional groups in $\mathrm{GO}$ which includes carboxyl $(\mathrm{C}=\mathrm{O})$, hydroxyl $(\mathrm{C}-\mathrm{OH})$ and epoxy $(\mathrm{C}-\mathrm{O}-\mathrm{C})$, the interaction between GO and polymer could be enhanced with improved hydrophilic [19, 20]. Observations on characteristic peaks of $\mathrm{GO}$ basically showed that by increasing GO concentration, the peaks also increase. (a)
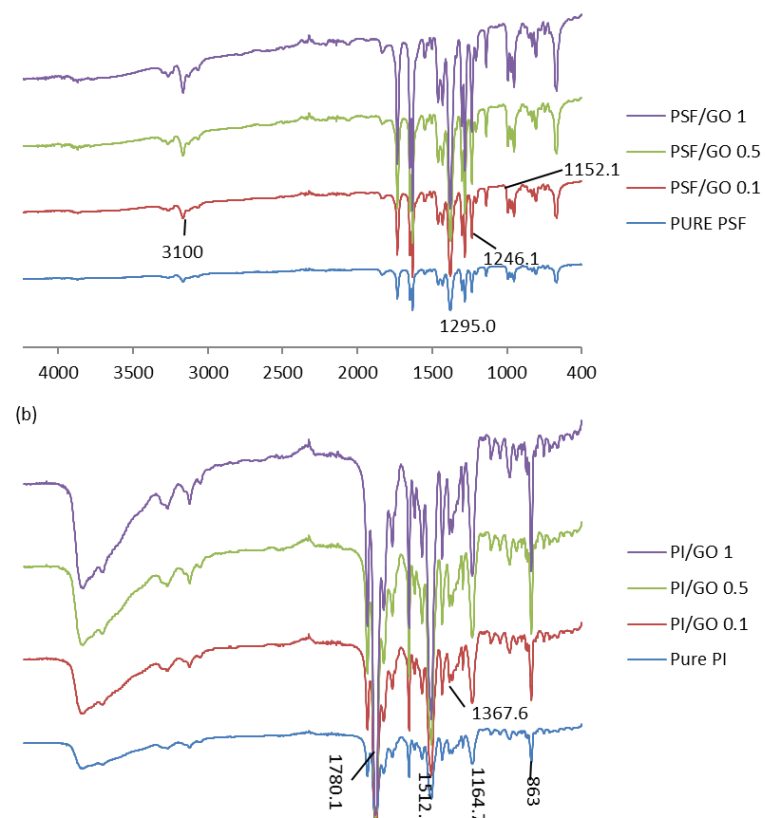

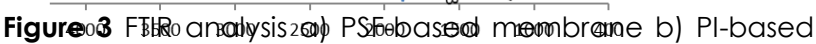
membrane

\subsection{Contact Angle Analysis}

In Table 2, it can be seen that pure PI membrane has the highest contact angle of $91^{\circ}$. It was shown that the addition of $G O$, contact angle decreased due to the addition of hydrophilic groups which includes carboxyl $(\mathrm{C}=\mathrm{O})$, hydroxyl $(\mathrm{C}-\mathrm{OH})$ and epoxy $(\mathrm{C}-\mathrm{O}-\mathrm{C})$. Furthermore, the lowest contact angle in PI-based membrane is around $58^{\circ}$ which indicates more hydrophilic membrane surface. As for PSF-based membrane, the highest contact angle belongs to pure PSF which is around 690 while the lowest is around $65^{\circ}$. Besides, these observations can be supported by previous studies which show that the addition of GO into membrane has decreased the contact angle due to addition of hydrophilic groups $[20,23,25]$.

Table 2 Contact angle

\begin{tabular}{lc}
\hline Sample & Contact Angle \\
\hline Pure PI & $91.4 \pm 0.07$ \\
PI/GO0.1 & $88.9 \pm 0.07$ \\
PI/GO 0.5 & $84.7 \pm 0.08$ \\
PI/GO 1 & $58.4 \pm 0.07$ \\
Pure PSF & $69.7 \pm 4.35$ \\
PSF/GO 0.1 & $68.9 \pm 0.03$ \\
PSF/GO 0.5 & $67.2 \pm 0.04$ \\
PSF/GO 1 & $65.9 \pm 0.04$ \\
\hline
\end{tabular}




\subsection{Zeta Potential Analysis}

The surface charge of membranes is mostly described by surface zeta potential which is determined by electro-kinetic measurements [25, 26]. Basically, if both membrane and molecules have the same charge, there will be repulsion which leads to less fouling. However if they are in opposite charge, there will be attractive forces which leads to easy fouling and reducing the performance [27]. As can be seen in Figure 4, the surface zeta potential for all membranes is negative which is due to the existence of electronegative functional groups $[20,26]$. It was also observed that as the GO concentration increased, the zeta potential also increased due to homogenous dispersion of more functional groups in mixed matrix membrane. This can be supported by a study which reported that the appearance of negative charge surface by adding GO into membrane takes place during phase inversion process when hydrophilic functional groups in GO move to the surface [26]. Furthermore, it can be determined that the zeta potential for $\mathrm{Pl}$ based membranes is higher than PSF-based membrane. Increasing the concentration of GO and preparing a homogenous solution by blending GO into the membrane, caused an increase in hydrophilic groups density, hence leads to higher negative surface charge which was also supported by studies done by Zhao et al. [26]. Furthermore, having a high surface charge on membrane, leads to less fouling of the membrane which leads to better performance [29]. Finally, it can be concluded that since Pl-based membrane has higher negative surface charge, it is better compared to PSF-based membranes.

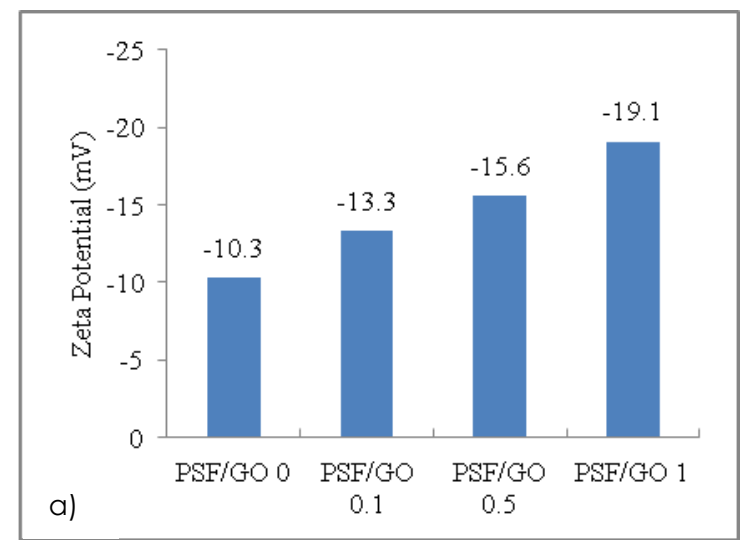

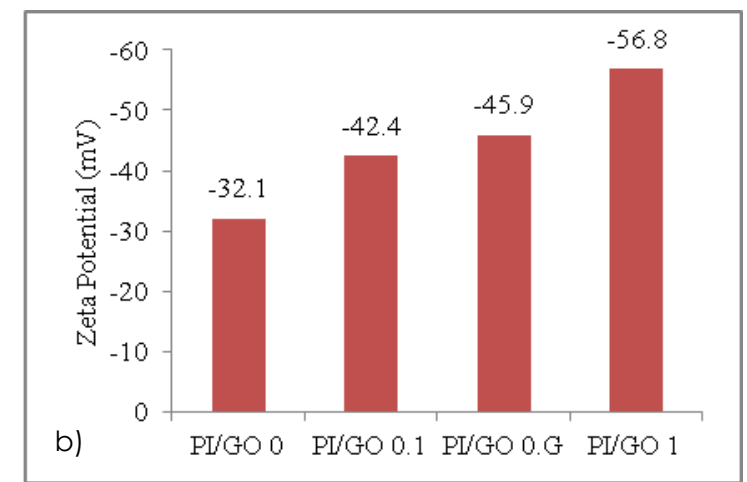

Figure 4 Zeta potential vs GO content a) PSF-based membrane, b) PI-based membranes

\subsection{Mechanical Properties}

Figure 5 shows peak load of each membrane vs GO content. Increasing the concentration of GO, increased tensile strength due to the enhancement in membrane structural strength [30]. It can also be determined that the tensile strength for PI based membranes was much higher than PSF based membranes which might possibly be due to better interaction of $\mathrm{GO}$ with PI [31]. Furthermore, it can be observed from the graph that PI/GO with 1 wt\% concentration has a higher peak load of $2778.5 \mathrm{~g}$, while the lowest peak load was $1522.5 \mathrm{~g}$ for pure PSF. The result showed that Pl-based membranes yield higher tensile strength which signifies better mechanical properties compared to PSF-based membranes.

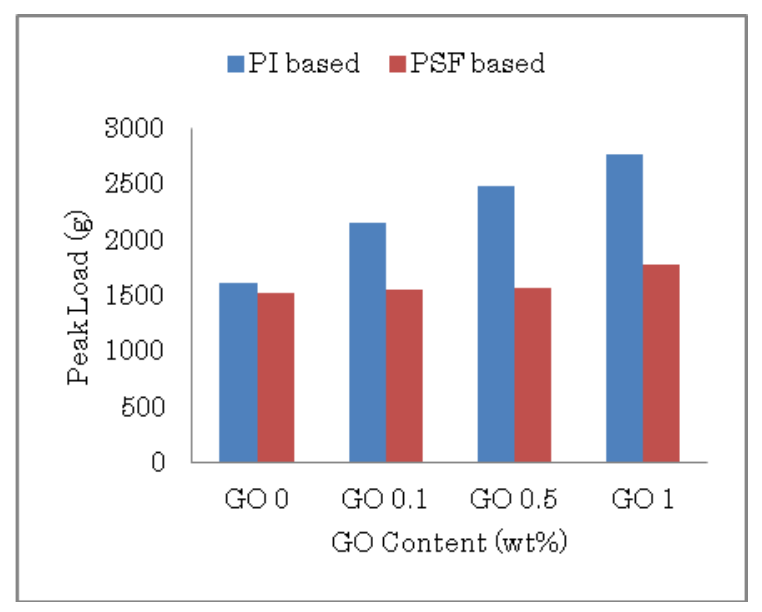

Figure 5 Tensile strength vs GO content 


\subsection{FESEM Analysis}

As shown in Figure 6 (a), some pores were found in pure PSF membrane. However, for PSF/GO 1 wt\% (see Figure 6 (b)), smoother surface can be seen which is due to the development of integrated selective skin layer that led to less formation of open porous structure causing generation of selective layer [30, 31]. Meanwhile, cross-sectional image of PSF membrane incorporated with GO 1 wt\% revealed long finger-like pores which are larger at the bottom part of the membrane. The shape of the pores was also different as can be seen in the cross-sectional image of pure PSF (see Figure 6 (e)). Several studies on this have determined that addition of $G O$ into the PSF membranes, changed the pore shape which might affect the gas permeation properties [20,34]. It was also observed that addition of GO into the PSF, caused changes in the pore size which might be due to the increase in viscosity value [19].

With respect to Pl-based membranes, pores were found in pure PI membrane while for PI/GO $1 \mathrm{wt \%}$, due to addition of $\mathrm{GO}$, the skin layer of the membrane is more dense which leads to lower number of pores and emerge of macroscopic defect. (see Figures 6 (c) and (d)). Cross sectional images (see Figures 6 (g) and (h)) also showed no significant difference. In addition, it can be determined from the cross section image of PI/GO 1 wt\% (see Figure $6(h))$ that a dense skin top layer was formed, whereas pure PI usually has a sponge like structure. This observation on the addition of $G O$ is supported by $\mathrm{Ge}$ et al. who stated that due to GO homogeneous dispersion in the polymeric matrix based of $\mathrm{Pl}$ and $\mathrm{GO}$ interaction, the surface is smooth, and no cracks, pores or other defects can be observed [22].

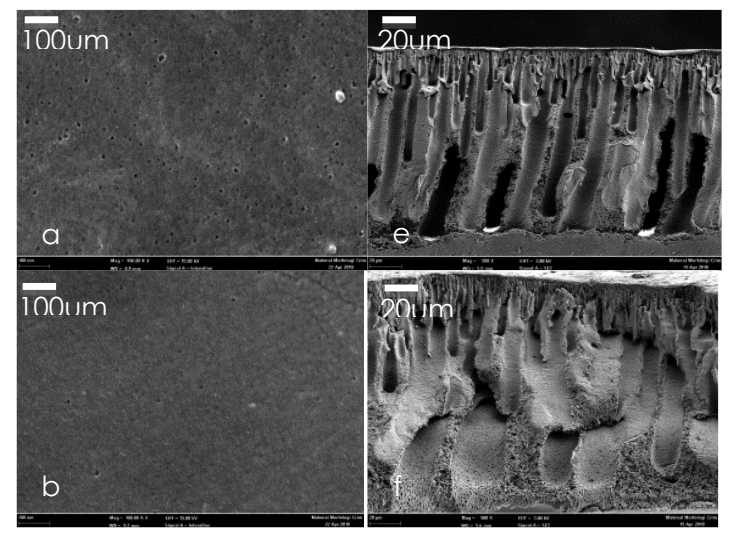

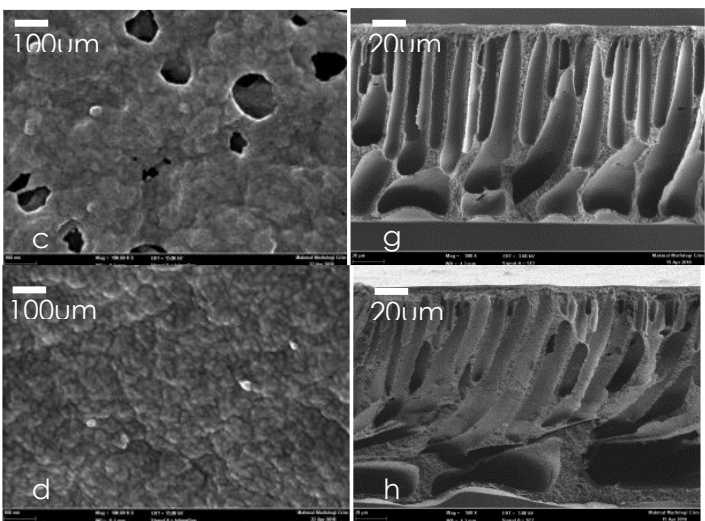

Figure 6 Membrane surface (a-d) with magnification of 100.00KX and cross section (e-h) with magnification of 500X, Pure PSF ( $a$ and e); PSF/GO 1wt\% (b and f); pure PI (c and g); PI/GO Iwt\% (d and h)

\subsection{Pressure Effect on Gas Permeation}

The gas permeation properties of the produced membranes were evaluated as one of the main parameters in membrane gas separation.

\section{a) Gas Permeation for PSF-based Membranes}

Figures 7 (a) and (b) show the effects of adding GO into PSF polymer on both $\mathrm{CO}_{2}$ and $\mathrm{H}_{2}$ permeability. As can be seen from Figure 7 (a) hydrogen permeability increases by increasing $\mathrm{GO}$ concentration from 0 to 1 $\mathrm{w}+\%$. It can also be determined from the figure that the permeability change is almost steady for all PSFbased membranes. The highest permeability was for PSF membranes incorporated with GO with 1 wt\% at 3 bar which was 439 GPU. On the other hand, the lowest permeability was for pure PSF at 5 bar which was 133 GPU. According to Kapantaidakis et al. [35] the permeability of gases like $\mathrm{H}_{2}, \mathrm{He}, \mathrm{N}_{2}$ and $\mathrm{O}_{2}$ have no interaction with membrane matrix; by increasing pressure, the permeability remains almost steady. A similar effect can be seen in Figure 7 (a). Several studies have shown that at a higher gas sorption, compression of membrane and plasticization can be met by increasing the pressure [4]. Basically, it means as the pressure increases, more gas molecules attach to the surface of the membrane which cause higher gas sorption. The membrane compaction or fouling is a phenomenon that causes a decrease in membrane transport properties especially in pressure driven processes which is blockage of membrane surface and pores [36]. With respect to plasticization, it usually occurs at high pressure which mainly affect the physical properties of the membrane in contact with $\mathrm{CO}_{2}$ [37]. Furthermore, it has been proven that by increasing the pressure, diffusion also increases. However due to the compaction of membrane, increasing the pressure leads to less diffusion of hydrogen gas which also leads to less permeability $[4,38]$. A similar observation can be made for pure PSF membrane as the permeability increases at first and then decreases. 
On the other hand, in Figure 7 (b) it can be seen that adding GO into PSF membrane and increasing its concentration, increased $\mathrm{CO}_{2}$ permeability. It can also be determined from the figure that by increasing the pressure; the permeability of the gases through the membranes incorporated with GO decreased. This is probably due to the decrease in amount of available free volume [39]. It can also be determined from Figure 7(b) PSF/GO 1 wt\% has the highest permeability of 288 GPU at 1 bar, while pure PSF has the lowest permeability which is 7 GPU at 5 bar. It has been proven that the addition of GO into PSF polymer, increased $\mathrm{CO}_{2}$ permeability due to the high adsorption properties of $\mathrm{GO}$ toward $\mathrm{CO}_{2}$. Furthermore, GO contains an active functional group which improves GO and PSF interaction with each other preventing interphase problems between GO and PSF resulting in better GO dispersion. Hence, it improves $\mathrm{CO}_{2}$ permeation $[19,26,40]$.

(a)

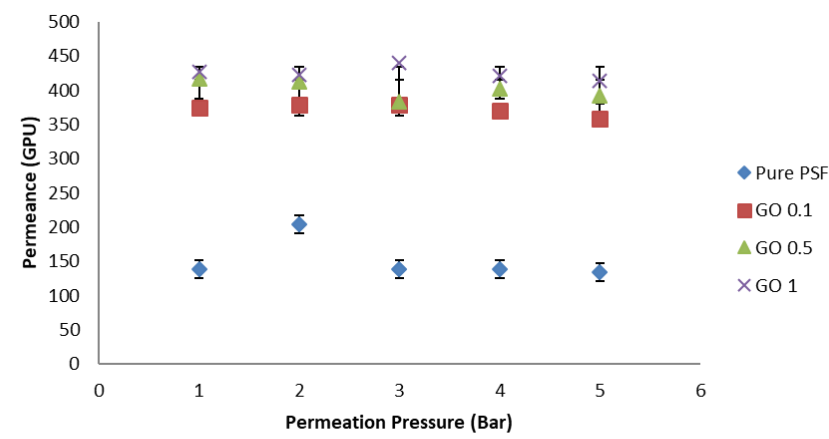

(b)

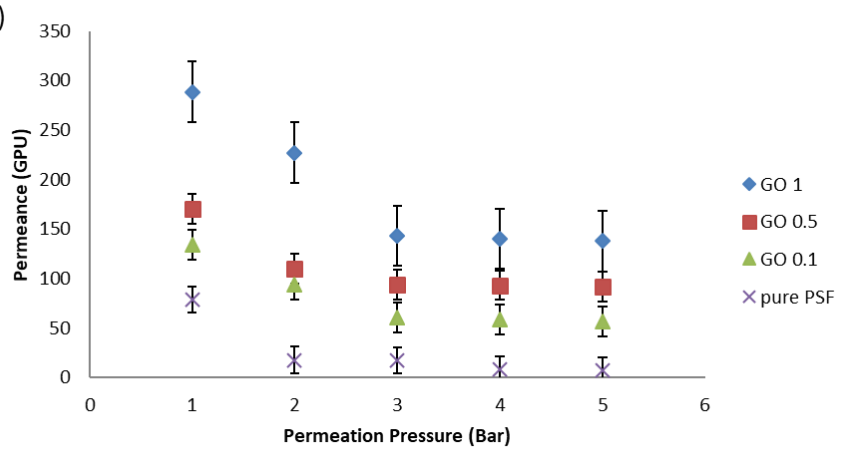

Figure 7 Gas permeation properties for PSF-based membrane at $25^{\circ} \mathrm{C}$ a) $\mathrm{H}_{2}$ permeability b) $\mathrm{CO}_{2}$ permeability

\section{b) Gas Permeation for Pl-based Membranes}

Figure 8 shows the effects of both pressure and concentration on gas permeation. It can be seen in Figure $8(a)$ that increasing the pressure, permeability of hydrogen in all membranes has insignificant changes. Besides, it also shows that as the concentration of GO increases the permeability of hydrogen also increases which is due to GOs' adsorption properties towards gas. The highest permeability recorded was for $\mathrm{PI}$ membranes incorporated with $\mathrm{GO}$ with concentration of $1 \mathrm{wt \%}$ at
1 bar which was 501GPU and the lowest was observed at 5 bar for pure PI which was 92 GPU.

By increasing the pressure, the permeability of $\mathrm{CO}_{2}$ decreases which might be due to the deduction in free volume (see Figure 8 (b). Furthermore, it can be seen that increasing the concentration of GO, increases the permeability of $\mathrm{CO}_{2}$. The highest permeability was recorded for $\mathrm{PI}$ membranes incorporated with GO with 1 wt\% at 1 bar which was 595 GPU. On the other hand, pure PI at 5 bar had the lowest permeability which was 57 GPU.

(a)
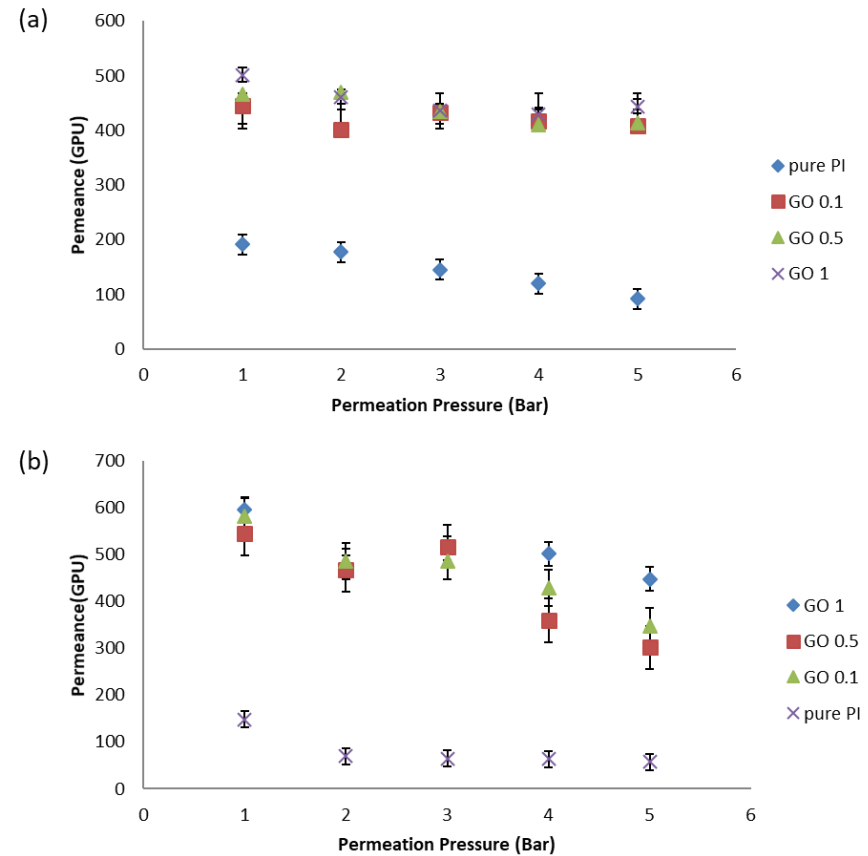

Figure 8 Gas permeation properties for PI-based membrane at $25^{\circ} \mathrm{C}$ a) $\mathrm{H}_{2}$ permeability b) $\mathrm{CO}_{2}$ permeability

\subsection{Gas Selectivity through Membranes}

Finally, as shown in Figure 9 the $\mathrm{H}_{2} / \mathrm{CO}_{2}$ selectivity in Pl-based membranes was higher than in PSF-based membranes at 5 bar. The highest selectivity belongs to PI/GO 1wt \% which was 1.3 while the lowest was 0.05 and belongs to pure PSF membrane. Thus it can be determined that PI-based membranes have the best results. In addition, in this category, $\mathrm{Pl}$ membranes incorporated with GO with 1 wt\% showed the best results. These results can be supported by analysis in the previous section, that as Pl-based membranes have better physicochemical properties especially for PI/GO 1 wt\% which has higher negative surface charge and the least contact angle which resulted in better performance. The drop in PI/GO $0.5 \mathrm{wt} \%$ is related to permeability which might be due to incomplete dispersion of $\mathrm{GO}$ into polymeric base [26]. 


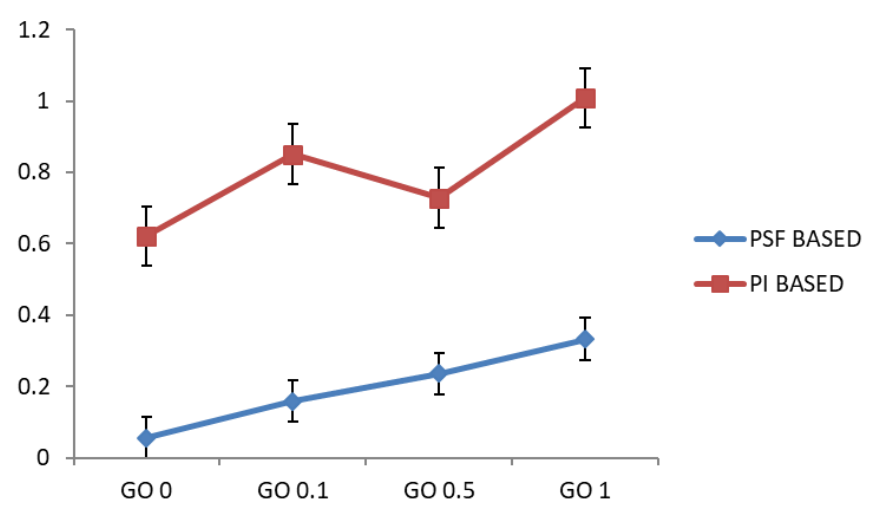

Figure 9 Selectivity vs GO concentration for PSF-based and PI-based membranes at 5 bar

\subsection{Gas Composition Analysis}

Gas composition was analysed after permeation of mixed $\mathrm{H}_{2} / \mathrm{CO}_{2}$ with $50 / 50$ concentration. From Table 3 it can be seen that hydrogen composition was higher for each sample. Furthermore, hydrogen composition was slightly higher in Pl-based membranes. It was also observed that the composition of hydrogen for membranes incorporated with GO with 1 wt\% has a higher hydrogen composition indicating that more hydrogen pass through the membrane. The findings of this study can be supported by several studies which reported that membranes incorporated with GO, smaller molecules pass through more than the bigger molecules $[19,41]$.

Table 3 Gas composition after gas permeation test

\begin{tabular}{lcc}
\hline Sample & $\mathrm{CO}_{2}$ Composition \% & $\mathbf{H}_{2}$ Composition\% \\
\hline Pure PI & 24 & 76 \\
PI/GO Iwt $\%$ & 17 & 83 \\
Pure PSF & 24 & 76 \\
PSF/GO Iwt\% & 18 & 82 \\
\hline
\end{tabular}

\subsection{CONCLUSION}

The performance of PSF-based and PI-based membranes for $\mathrm{CO} 2$ and $\mathrm{H} 2$ permeance and selectivity at pressures of 1 to 5 bar was successfully measured and characterized with the incorporation of various GO concentrations. The results from gas permeability and selectivity shows that PI/GO with concentration of $1 \mathrm{wt} \%$ has the highest performance with $\mathrm{H} 2$ permeability of 501 GPU and $\mathrm{CO} 2$ permeability of $595 \mathrm{GPU}$ at 1 bar, while for $\mathrm{H} 2 / \mathrm{CO} 2$ selectivity, the highest belongs to PI/ GO 1 wt\% of 1.3 at 5 bar. Meanwhile, gas composition analysis showed that hydrogen composition after permeation through the membrane was highest for PI/GO 1 wt\% which was $83 \%$. As for FTIR analysis, oxygenated functional groups were observed with GO addition. The zeta potential analysis showed that surface charge negatively increased with the addition of GO and the highest was $-56 \mathrm{mV}$ which belongs to PI/GO $1 w+\%$. Besides, FESEM analyses showed the change from droplet-like shape to finger-like for PSF-based membranes and denser structures for PI-based membranes. The addition of GO also leads to higher hydrophilicity with the contact angle of 58 for PI/GO 1 wt\%. It could be concluded that PI/GO 1 wt\% membranes has exhibited enhanced gas permeation and physicochemical properties compared to PSF membranes with the incorporation of GO.

\section{Acknowledgement}

The authors would like to thank CESPRO, Chemical Engineering Program, Faculty of Engineering \& Built Environment, UKM Bangi for the research facilities, and support from the GUP/2016/086 research grant and also Ministry of Higher Education for FRGS/1/2018/TKO2/UKM/02/2 research grant.

\section{References}

[1] Mulder, J. 2012. Basic Principles of Membrane Technology. Springer Science \& Business Media. DOI: 10.1007/978-94009-1766-8.

[2] Panapitiya, N., Wijenayake, S., Nguyen, D., Karunaweera, C., Huang, Y., Balkus, K., and Ferraris, J. 2016. Compatibilized Immiscible Polymer Blends for Gas Separations. Materials. 9(8): 643. DOI: 10.3390/ma9080643.

[3] Joshi, R. K., Alwarappan, S., Yoshimura, M., Sahajwalla, V., and Nishina, Y. 2015. Graphene Oxide: The New Membrane Material. Applied Materials Today. 1(1): 1-12. DOI: https://doi.org/10.1016/j.apmt.2015.06.002.

[4] Mohamad, I. N., Rohani, R., Mastar, M. S., Nor, M. T. M., and Jahim, J. M. 2016. Permeation Properties of Polymeric Membranes for Biohydrogen Purification. International Journal of Hydrogen Energy. 41 (7): 4474-4488.

DOI: https://doi.org/10.1016/j.jjhydene.2015.08.002.

[5] Yoon, H. W., Cho, Y. H., and Park, H. B. 2016. GrapheneBased Membranes: Status and Prospects. Philosophical Transactions of the Royal Society A. 374(2060): 20150024. DOI: 10.1098/rsta.2015.0024

[6] Huang, H. L., and Yang, S. 2006. Filtration Characteristics of Polysulfone Membrane Filters. Journal of Aerosol Science. 37(10): 1198-1208.

DOI: https://doi.org/10.1016/j.jaerosci.2005.11.010.

[7] Jiang, Z., Zhao, X., Fu, Y., and Manthiram, A. 2012. Composite Membranes based on Sulfonated Poly (ether ether ketone) and SDBS-adsorbed Graphene Oxide for Direct Methanol Fuel Cells. Journal of Materials Chemistry. 22(47): 24862-24869. DOI: 10.1039/C2JM35571 J.

[8] Guzmán-Lucero, D., Palomeque-Santiago, J. F., Camacho-Zúñiga, C., Ruiz-Treviño, F. A., Guzmán, J., Galicia-Aguilar, A., and Aguilar-Lugo, C. 2015. Gas Permeation Properties of Soluble Aromatic Polyimides Based on 4-Fluoro-4, 4'-Diaminotriphenylmethane. Materials. 8(4): 1951-1965.

DOI: https://doi.org/10.3390/ma8041951.

[9] Rafiq, S., Man, Z., Maitra, S., Maulud, A., Ahmad, F., and Muhammad, N. 2011. Preparation of Asymmetric Polysulfone/Polyimide Blended Membranes for $\mathrm{CO} 2$ Separation. Korean Journal of Chemical Engineering. 28(10), 2050-2056. DOI: 10.1007/s $11814-011-0053-1$.

[10] Park, H. B., Yoon, H. W., and Cho, Y. H. 2016. Graphene Oxide Membrane for Molecular Separation. Graphene Oxide: Fundamentals and Applications. 296. 
DOI: https://doi.org/10.1002/9781119069447.ch9.

[11] Mahmoudi, E., Ng, L. Y., Ba-Abbad, M. M., \& Mohammad, A. W. 2015. Novel Nanohybrid Polysulfone Membrane Embedded with Silver Nanoparticles on Graphene Oxide Nanoplates. Chemical Engineering Journal. 277: 1-10. DOI: https://doi.org/10.1016/j.cej.2015.04.107

[12] Momeni, S. M., and Pakizeh, M. 2013. Preparation, Characterization and Gas Permeation Study of PSf/MgO Nanocomposite Membrane. Brazilian Journal of Chemical Engineering. 30(3): 589-597.

DOI: http://dx.doi.org/10.1590/S0104-66322013000300016.

[13] Kertész, S., de Freitas, T. B., and Hodúr, C. 2014 Characterization of Polymer Membranes by Contact Angle Goniometer. Analecta Technica Szegedinensia. 8(2): 18-22.

DOI: https://doi.org/10.14232/analecta.2014.2.18-22.

[14] Breite, D., Went, M., Prager, A., and Schulze, A. 2015. Tailoring Membrane Surface Charges: A Novel Study on Electrostatic Interactions during Membrane Fouling. Polymers. 7(10): 2017-2030.

DOI: https://doi.org/10.3390/polym7101497.

[15] Mataram, A., Nasution, S., Wijaya, M. L., and Septano, G. 2017. Physical and Mechanical Properties of Membrane Polyacrylonitrile. MATEC Web of Conferences. EDP Sciences. 101: 01010.

DOI: ttps://doi.org/10.1051/matecconf/201710101010.

[16] Tylkowski, B., and Tsibranska, I. 2015. Overview of Main Techniques Used for Membrane Characterization. Journal of Chemical Technology \& Metallurgy. 50(1): 3-12

[17] Mohamad, I. N., Rohani, R., Mastar, M. S., Nor, M. T. M., \& Jahim, J. M. 2016. Permeation Properties of Polymeric Membranes for Biohydrogen Purification. International Journal of Hydrogen Energy. 41 (7): 4474-4488.

DOI: https://doi.org/10.1016/j.jjhydene.2015.08.002.

[18] Zhao, C., Xu, X., Chen, J., and Yang, F. 2013. Effect of Graphene Oxide Concentration on the Morphologies and Antifouling Properties of PVDF Ultrafiltration Membranes. Journal of Environmental Chemical Engineering. 1 (3): 349354. DOI: https://doi.org/10.1016/j.jece.2013.05.014.

[19] Zahri, K., Goh, P. S., and Ismail, A. F. 2016. The Incorporation of Graphene Oxide into Polysulfone Mixed Matrix Membrane for $\mathrm{CO} 2 / \mathrm{CH} 4$ Separation. IOP Conference Series: Earth and Environmental Science. 36(1): 012007. IOP Publishing.

DOl: https://doi.org/10.1088/1755-1315/36/1/012007.

[20] Rezaee, R., Nasseri, S., Mahvi, A. H., Nabizadeh, R. Mousavi, S. A., Rashidi, A., and Nazmara, S. 2015. Fabrication and Characterization of a Polysulfonegraphene Oxide Nanocomposite Membrane for Arsenate Rejection from Water. Journal of Environmental Health Science and Engineering. 13(1): 61. DOI: 10.1186/s40201015-0217-8.

[21] Rafiq, S., Man, Z., Maitra, S., Muhammad, N., and Ahmad. 2012. Kinetics of Thermal Degradation of Polysulfone/polyimide Blended Polymeric Membranes. Journal of Applied Polymer Science. 123(6): 3755-3763. DOI: https://doi.org/10.1002/app.34862.

[22] Ge, B. S., Wang, T., Sun, H. X., Gao, W., and Zhao, H. R. 2018. Preparation of Mixed Matrix Membranes based on Polyimide and Aminated Graphene Oxide for $\mathrm{CO} 2$ Separation. Polymers for Advanced Technologies. 4(29): 1334-1343. DOI: https://doi.org/10.1002/pat.4245.

[23] Feng, B., XU, K., and Huang, A. 2017. Synthesis of Graphene Oxide/Polyimide Mixed Matrix Membranes for Desalination. RSC Advances. 7(4): 221 1-2217. DOI: 10.1039/C6RA24974D.

[24] Ding, Z., Liu, X., Liu, Y., and Zhang, L. 2016. Enhancing the Compatibility, Hydrophilicity and Mechanical Properties of Polysulfone Ultrafiltration Membranes with Lignocellulose Nanofibrils. Polymers. 8(10): $349 . \quad$ DOI: https://doi.org/10.3390/polym8100349.

[25] Hurwitz, G., Guillen, G. R., and Hoek, E. M. 2010. Probing Polyamide Membrane Surface Charge, Zeta Potential, Wettability, and Hydrophilicity with Contact Angle
Measurements. Journal of Membrane Science. 349(1-2): 349-357. DOI: 0.1016/j.memsci.2009.11.063.

[26] Zhao, L., Cheng, C., Chen, Y. F., Wang, T., Du, C. H., and Wu, L. G. 2015. Enhancement on the Permeation Performance of Polyimide Mixed Matrix Membranes by Incorporation of Graphene Oxide with Different Oxidation Degrees. Polymers for Advanced Technologies. 26(4): 330337. DOI: https://doi.org/10.1002/pat.3456.

[27] Williams, P. M. 2016. Membrane Charge (Zeta Potential) Effect. Encyclopedia of Membranes. 1-2. DOI: https://doi.org/10.1007/978-3-642-40872-4_1003-1.

[28] Lu, G. W., and Gao, P. 2010. Emulsions and Microemulsions for Topical and Transdermal Drug Delivery. Handbook of Non-Invasive Drug Delivery Systems. 59-94. DOI: https://doi.org/10.1016/B978-0-8155-2025-2.10003-4.

[29] Manawi, Y., Kochkodan, V., Mahmoudi, E., Johnson, D. J., Mohammad, A. W., and Atieh, M. A. 2017. Characterization and Separation Performance of a Novel Polyethersulfone Membrane Blended with Acacia Gum. Scientific Reports. 7(1): 15831. DOI: 10.1038/s41598-01714735-9.

[30] Ismail, N. M., Jakariah, N. R., Bolong, N., Anissuzaman, S. M., Nordin, N. A. H. M., and Razali, A. R. 2017. Effect of Polymer Concentration on the Morphology and Mechanical Properties of Asymmetric Polysulfone (PSf) Membrane. Journal of Applied Membrane Science \& Technology. 21(1).

DOI: https://doi.org/10.11113/amst.v21i1.107.

[31] Ammar, A., Al-Enizi, A. M., AlMaadeed, M. A., and Karim, A. 2016. Influence of Graphene Oxide on Mechanical, Morphological, Barrier, and Electrical Properties of Polymer Membranes. Arabian Journal of Chemistry. 9(2): 274-286. DOI: https://doi.org/10.1016/j.arabjc.2015.07.006.

[32] Paulchamy, B., Arthi, G., and Lignesh, B. D. 2015. A Simple Approach to Stepwise Synthesis of Graphene Oxide Nanomaterial. Journal of Nanomedicine \& Nanotechnology. 6(1): 1. DOI: 10.4172/2157-7439.1000253.

[33] Zahri, K., Wong, K. C., Goh, P. S., and Ismail, A. F. 2016. Graphene Oxide/polysulfone Hollow Fiber Mixed Matrix Membranes for Gas Separation. RSC Advances. 6(92): 89130-89139. DOI: 10.1039/C6RA16820E.

[34] Park, M. J., Phuntsho, S., He, T., Nisola, G. M., Tijing, L. D., Li, X. M., and Shon, H. K. 2015. Graphene Oxide Incorporated Polysulfone Substrate for the Fabrication of Flat-Sheet ThinFilm Composite Forward Osmosis Membranes. Journal of Membrane Science. 493: 496-507. DOI: 10.1016/j.memsci.2015.06.053.

[35] Kapantaidakis, G. C., Kaldis, S. P., Dabou, X. S., and Sakellaropoulos, G. P. 1996. Gas Permeation through PSFPI Miscible Blend Membranes. Journal of Membrane Science. 110(2): 239-247. DOI: https://doi.org/10.1016/0376-7388(95)00265-0.

[36] Volkov, A. 2015. Membrane Compaction. Encyclopedia of Membranes. E. Drioli and L. Giorno, Editors. Springer Berlin Heidelberg: Berlin, Heidelberg. 1-2. DOI: https://doi.org/10.1007/978-3-642-40872-4_1404-2.

[37] Wessling, M., Schoeman, S., Van der Boomgaard, T., and Smolders, C. A. 1991. Plasticization of Gas Separation Membranes. Gas Separation \& Purification. 5(4): 222-228. DOI: 10.1016/0950-4214(91)80028-4.

[38] Shamsabadi, A. A., Kargari, A., and Babaheidari, M. B. 2014. Preparation, Characterization and Gas Permeation Properties of PDMS/PEI Composite Asymmetric Membrane for Effective Separation of Hydrogen from H2/CH4 Mixed Gas. International Journal of Hydrogen Energy. 39(3): 1410-1419. DOI: https://doi.org/10.1016/j.ijhydene.2013.11.004.

[39] Shen, J., Zhang, M., Liu, G., Guan, K., and Jin, W. 2016. Size Effects of Graphene Oxide on Mixed Matrix Membranes for CO2 Separation. AlChE Journal. 62(8): 2843-2852. DOI: https://doi.org/10.1002/aic.15260.

[40] Li, H., Song, Z., Zhang, X., Huang, Y., Li, S., Mao, Y., and Yu, M. 2013. Ultrathin, Molecular-sieving Graphene Oxide 
Membranes for Selective Hydrogen Separation. Science. 342(6154), 95-98. DOI: 10.1126/science.1236686.

[41] Li, X., Cheng, Y., Zhang, H., Wang, S., Jiang, Z., Guo, R., \& Wu, H. 2015. Efficient CO2 Capture by Functionalized Graphene Oxide Nanosheets as Fillers to Fabricate Multi-
Permselective Mixed Matrix Membranes. ACS Applied Materials \& Interfaces. 7(9), 5528-5537. DOI: 10.1021/acsami.5b00106. 